\title{
Editor Note: Journal of Aquaculture Research \& Development Vol 7 Issue 12
}

\author{
Mauro Lenzi*
}

Lagoon Ecology and Aquaculture Laboratory (LEALab), Orbetello Pesca Lagunare Company, Italy

*Corresponding author: Mauro Lenzi, Lagoon Ecology and Aquaculture Laboratory (LEALab), Orbetello Pesca Lagunare Company, Italy, Tel: +39 3487 304274; Fax: +390564 867572; E-mail: lealab1@gmail.com

Rec date: Dec 21, 2016; Acc date: Dec 22, 2016; Pub date: Dec 24, 2016

Copyright: (c) 2016 Lenzi M. This is an open-access article distributed under the terms of the Creative Commons Attribution License, which permits unrestricted use, distribution, and reproduction in any medium, provided the original author and source are credited.

\section{Introduction}

With the growing human population over time, need for the expansion of food sources got ample of importance. Involvement of scientific approaches in agricultural sector played sovereign role to flourish with more production and to provide adequate hand-tomouth connection. Apart from the improvement in crop variety in agricultural field, aquatic food products also got scientific nourishment and included under the head of 'Aquaculture', which basically deals with the farming of aquatic organisms such as fish, crustaceans, molluscs, aquatic plants and algae. The study in this particular field includes breeding freshwater and saltwater organisms under controlled conditions for commercial use. Aquaculture also focused with the nutritional point of view, which mainly concentrates in providing balanced food at an affordable cost, and now trying to use renewable sources of staple foods for farmed fish products.

The Journal of Aquaculture Research and Development deals with publishing scientific articles associated with freshwater aquaculture, brackish water aquaculture, and marine aquaculture in relation with human consumption. The Journal also comprises research and development in fish farming, nutritional perspective and also environmental part associated with aquaculture. The present issue of The Journal of Aquaculture Research and Development in volume 7 issue 12 includes the relevant and timely information which consist of the key concept of water conservation, Barramundi farming, Water Quality Index survey, prokaryotic and eukaryotic microbes in aquaculture ponds, and endosymbiotic bacteria of vent mussel.

Utilization of treated water plays a vital role in aquaculture. It encourages the efficient use of decreasing global water resources and helps in reducing harmful effect of waste-water from aquaculture on the sustained environment. The outcome of the work done by Akinwole et al. suggested that, some plant materials can be used effectively as coagulants in the treatment and reuse of water. In this instance Moringa oleifera seed can be used effectively for the wastewater treatment as in the culture of Clarias gariepinus juveniles without any adverse effects on the growth and feed usage. Alum had an unfavorable impact on the survival and growth of catfish juveniles. Fish farmers should be persuaded to use Moringa seeds in water treatment plants as an alternative of alum or other chemicals to support water conservation and wastewater reuse [1].

Globally, Barramundi (Lates calcarifer) is one of the commercially dominant species, with its aquaculture practice comparatively new in Bangladesh. The study of Siddik et al. indicates the on growing farming systems of barramundi, its cultural limitations, economic importance and availability in coastal Bangladesh. Even if the farming practice of this species is comparatively new, it is in high demand among the consumers because of its taste, high flesh content and nutritional values compared to other commercially important species found in that region. Because of the shortage of seed, Farmers are employing semi-intensive and extensive farming procedures along with other species in Bangladesh except some of the normal nurseries which rear natural sources fertilized eggs and fry to fingerling size. Generally, a switch from large scale capture fishery to culture across the Southwestern part of Bangladesh appears to be a dominant trend of barramundi farming in this area [2].

Branching of the river Nile into irrigation canals continues for many kilometers, where each part is regarded as a semi-independent ecosystem. The study by Khallaf et al. highlighted some of these canals namely, Bahr Shebeen and Alkhadraweya Canals, which are located at the Minufiya Governorate, and unfold all over other Governorates in the Delta of Egypt. The study comprises the water quality data, which includes the analysis and discussion of parameters like $\mathrm{pH}$, dissolved oxygen, electrical conductivity, total hardness, total dissolved solids like Chlorine, Magnesium, Calcium, Zinc, Manganese, Iron, Copper, Nitrate, phosphates. The study provides significant insight into the farming promises of each of the canal depending on the fish growth condition, the favorability of each ecosystem for fish farming. Thereafter, Water Quality Index was surveyed and recommended for the Canals [3].

The study by Hou et al. deals with the community compositions and dominant taxonomies of prokaryotic and eukaryotic microorganisms in various samples of the water from different Pacific white shrimp ponds. Results of abundance and diversity indicate that prokaryotic and eukaryotic microorganisms are having complicated community compositions in those ponds. Their study reveals that the larger distribution of microbial community is further associated with environmental factors. Therefore, the main objective should be the impacts of environmental conditions on the variety and distribution of microbial community, and the interactions between species and environmental factors in the shrimp pond ecosystem. Therefore, it is of great significance to analyze the community compositions of prokaryotic and eukaryotic microbes in aquaculture ponds [4].

The study by Barros et al. analyses the immunomodulatory effects of Vibrio diabolicus on Bathymodiolus azoricus during prolonged acclimatization at atmospheric pressure. This experimental study indicates prospects for demonstrating an acclimatization period and impacts of endosymbiont on host immune gene expression, confirming earlier findings which suggest that different timedependent immune gene responses in $B$. azoricus are related to endosymbiont bacteria inside vent mussel gills. In this study, the functional immunological capabilities of gill tissues of B. azoricus were discussed while doing acclimatization test in an aquarium at 
Citation: Lenzi M (2016) Editor Note: Journal of Aquaculture Research \& Development Vol 7 Issue 12. J Aquac Res Development 7: e112. doi: 10.4172/2155-9546.1000e112

Page 2 of 2

atmospheric pressure. These gene expression profile studies supported $B$. azoricus ability to deploy its immune system and to react against vibrio challenges. $B$. azoricus is presented as an appropriate model to test molecular interactions comprising host mediated immune recognition procedures and adaptation methods [5].

\section{References}

1. Akinwole AO, Dauda AB, Ololade OA (2016) Growth performance of African Catfish (Clarias gariepinus) juveniles reared in wastewater treated with alum and moringa oleifera seed. J Aquac Res Development 7: 460.

2. Siddik MAB, Islam MA, Hanif MA, Chaklader MR, Kleindienst R (2016) Barramundi, Lates calcarifer (Bloch, 1790): A new dimension to the fish farming in coastal Bangladesh. J Aquac Res Development 7: 461.
3. Khallaf EA, Galal M, Authman MMN, Zaid RA (2016) A comparative study on the water quality of two nilotic canals in the delta of Egypt. J Aquac Res Development 7: 462.

4. Hou D, Zeng S, Liu J, Yan M, Weng S, et al. (2016) Characterization of prokaryotic and eukaryotic microbial community in Pacific white shrimp ponds. J Aquac Res Development 7: 463.

5. Barros I, Mendes S, Rosa D, Santos RS, Bettencourt R (2016) Vibrio diabolicus immunomodulatory effects on bathymodiolus azoricus during longterm acclimatization at atmospheric pressure. J Aquac Res Development 7: 464 